\title{
POSISI TIDUR DALAM MENINGKATKAN KUALITAS TIDUR PASIEN CONGESTIVE HEART FAILURE
}

\author{
Sleep Position in Improving Sleep Quality of Congestive Heart Failure Patients \\ Dewi Nurviana Suharto*, Agusrianto, Dafrosia Darmi Manggasa, Firsya Dita Maulinda Liputo \\ Poltekkes Kemenkes Palu \\ *Email korespondensi: dewinurviana.suharto@gmail.com,
}

\begin{abstract}
ABSTRAK
Pendahuluan: Congestive heart failure adalah ketidakmampuan jantung untuk memompa darah dalam jumlah yang cukup untuk memenuhi kebutuhan jaringan terhadap oksigen dan nutrient. Masalah yang sering muncul pada pasien congestive heart failure salah satunya yaitu gangguan tidur. Penatalaksanaan gangguan tidur diantaranya mengunakan pendekatan farmakologis dan non farmakologis. Salah satu pendekatan non farmakologis adalah pengaturan posisi tidur lateral kanan dan semifowler. Tujuan penulisan mengidentifikasi studi literatur tentang posisi tidur dalam meningkatkan kualitas tidur pada pasien congestive heart failure. Metode penelusuran database yang digunakan dalam studi literature ini yaitu database elektronik seperti ScienceDirect dan website: google dan google scholar. Hasil penelitian ada 7 jurnal yang diidentifikasi dan diterbitkan dari 2015-2019. Hasil dari jurnal menunjukan bahwa pengaturan posisi tidur lateral kanan dan semifowler efektif mengatasi masalah gangguan tidur pada pasien CHF. Saran: diharapkan peran perawat dan peneliti selanjutnya agar dapat menerapkan intervensi pemberian posisi tidur lateral kanan dan semifowler untuk meningkatkan kualitas tidur pasien CHF.
\end{abstract}

Kata kunci: CHF; sleep position; sleep quality; right lateral position; semifowler;

\section{ABSTRACT}

Introduction: Congestive heart failure is the inability of the heart to pump enough blood to meet the tissue's needs for oxygen and nutrients. One of the problems that often arise in patients with congestive heart failure is sleep disorders. The management of sleep disorders includes using pharmacological and non-pharmacological approaches. One of the non-pharmacological approaches is the right lateral and semifowler sleep regulation. A useful aim: to identify a literature study on how sleep improves sleep quality in patients with congestive heart failure. Search Methods: The databases used in this literature study are electronic databases such as ScienceDirect and websites: google and google scholar. Results: 7 journals were identified and published from 2015-2019. The results of the journal show that the right lateral sleep control and semifowler are effective in overcoming sleep disorders in CHF patients. Suggestion: It is hoped that the role of nurses and future researchers can implement interventions in the right lateral and semifowler sleeping positions to improve the sleep quality of CHF patients.

Keywords : CHF; sleep position; sleep quality; right lateral position; semifowler;

https://doi.org/10.33860/mnj.v1i2.263

(C) 2020 by the authors. Submitted for possible open access publication under the terms and conditions of the Creative Commons Attribution (CC BY SA) license (https://creativecommons.org/licenses/by-sa/4.0/).

\section{PENDAHULUAN}

Congestive Heart Failure merupakan salah satu masalah kesehatan dalam sistem kardiovaskuler yang angka kejadiaannya terus meningkat. CHF adalah suatu keadaan yang progresif dengan prognosis yang buruk. ${ }^{1}$

Pada tahun 2016 tercatat sebanyak 17,5 juta orang di dunia mengalami gangguan kardiovaskular. CHF berkontribusi terhadap 287.000 kematian per 
tahun. ${ }^{2}$ Sedangkan penyakit CHF di Indonesia pada tahun 2018 prevalensi menunjukan sebesar $(1,5 \%)$, hal ini meningkat jika dibandingkan dengan tahun 2013 yaitu sebesar (0,13\%). Prevalensi CHF berdasarkan diagnosis dokter tertinggi di Kalimantan Utara yaitu sebesar $(2,2 \%)$, disusul Gorontalo dan Yogyakarta yaitu sebesar $(2,0 \%)$. Sedangkan Sulawesi Tengah menduduki peringkat ketiga dengan prevalensi sebesar $(1,9 \%){ }^{3}$

CHF menimbulkan berbagai gejala klinis yang dirasakan pasien, beberapa diantaranya adalah dispnea, ortopnea dan Paroximal Noctural Dyspnea. ${ }^{4}$ Dispnea mengakibatkan pasien sering terbangun di malam hari dan harus duduk atau berdiri untuk meringankan sesak. Hal ini berdampak pada terganggunya istirahat dan tidur pasien. Gejala yang paling umum terjadi yaitu rasa mengantuk sepanjang hari dan kesulitan tidur. Tidur merupakan suatu kegiatan yang sangat dibutuhkan oleh tubuh dan merupakan suatu kebutuhan dasar bagi manusia, dimana pada saat istirahat dan tidur tubuh melakukan pemulihan dan mengumpulkan stamina kembali dari aktivitas yang telah dilakukan selama terjaga sehingga dapat kembali ke kondisi yang lebih optimal. ${ }^{5}$

Salah satu masalah yang muncul akibat dari terganggunya tidur yaitu menurunnya kualitas tidur. Kualitas tidur merupakan suatu keadaan seseorang dapat dengan mudah untuk memulai tidur dan mempertahankan tidur, komponen dari kualitas tidur dapat digambarkan dengan lama waktu tidur dan keluhan - keluhan yang dirasakan diwaktu tidur dan saat bangun tidur. ${ }^{6}$

Penderita gagal jantung sering mengalami kualitas tidur yang buruk. Jantung yang sudah mengalami gangguan jika disertai dengan kualitas tidur yang buruk akan menyebabkan kerja jantung semakin berat, proses revitalisasi fisik dan psikologis menurun sehingga memperparah penyakit yang diderita dan tentu akan memperpanjang hari rawatan pada pasien dan berakhir dengan bertambahnya angka morbiditas. Oleh karena itu dibutuhkan intervensi dalam penanganannya, apalagi komponen kualitas tidur yang sering dialami penderita gagal jantung adalah latensi tidur yang panjang atau kesulitan untuk memulai tidur, berlanjut durasi tidur yang pendek dan berefek tidur yang tidak efisien, dimana dalam hal ini sangat dibutuhkan peran perawat sebagai pemberi asuhan keperawatan terutama dalam pemberian kenyamanan bagi pasien menjelang tidur. ${ }^{7}$
Dalam pemberian asuhan keperawatan intervensi yang dapat dilakukan untuk meningkatkan kualitas tidur pasien CHF yaitu dengan pengaturan posisi tidur. Posisi dalam tidur pada pasien gagal jantung sangat penting, hal ini dikarenakan posisi istirahat lateral kanan merupakan salah satu intervensi keperawatan yang dapat digunakan untuk membantu meningkatkan kualitas tidur dimana rata-rata perbedaan kualitas tidur sebelum dan setelah terapi posisi lateral kanan yaitu 19,09 dan $p$-value $=0,000$ ( $p$ value $<0,05)$. Hal ini menunjukkan peningkatan yang signifikan kualitas tidur pada pasien gagal jantung yang diberi intervensi. ${ }^{7}$ Selain posisi lateral kanan, posisi semifolwer juga dapat meningkatkan kualitas tidur pasien gagal jantung. Dimana terdapat perbedaan antara skor kualitas tidur sebelum dan sesudah diberikan posisi semi fowler $45^{\circ}$. Hal ini menandakan bahwa posisi tidur semi fowler $45^{\circ}$ efektif untuk meningkatkan kualitas tidur pasien gagal jantung. ${ }^{8}$

Berdasarkan uraian latar belakang di atas penulis tertarik untuk melakukan penelitian tentang Studi Literarur Posisi Tidur Dalam Meningkatkan Kualitas Tidur Pasien Congestive Heart Failure.

\section{METODE PENELUSURAN}

Strategi penelusuran menggunakan database elektronik seperti ScienceDirect dan website: google dan google scholar. Strategi pencarian menggunakan kata kunci tunggal atau gabungan dari sleep, sleep position, sleep quality, right lateral, semifowler dan CHF.

\section{HASIL PENELITIAN}

Berdasarkan hasil pencarian literatur dari 10 jurnal yang didapatkan, terdapat 7 jurnal yang memenuhi kriteria inklusi. Penelitian-penelitian tersebut mengidentifikasi pengaruh pengaturan posisi tidur pada pasien CHF. Pasien dengan diagnosa CHF sering mengalami masalah tidur. Penatalaksanaan yang dapat dilakukan salah satunya dengan pendekatan non farmakolgi yaitu pengaturan posisi tidur.

Pada penelitian yang dilakukan oleh Pinna et al., (2015) dengan menggunakan desain penelitian group comparisons dan responden sebanyak 120 orang yang terdiri dari 29 pasien dengan OSA dan 91 pasien dengan CSA. Hasil penelitian menunjukkan posisi lateral dapat menurunkan tingkat keparahan 
gangguan pernafasan saat tidur pasien CHF dengan nilai $(p$-value $=0,0001)$.

Penelitian yang dilakukan oleh Yesni (2019) dengan desain penelitian quasi eksperimen pre and posttest control group dengan responden sebanyak 29 orang yang terdiri dari 15 kelompok intervensi dan 14 kelompok kontrol. Kriteria inklusi dalam penelitian ini adalah beragama islam, pasien gagal jantung derajat I dan II. Intervensi diberikan pada malam menjelang pasien tidur yaitu selama 3 hari. Setelah diberikan intervensi, didapatkan hasil bahwa terdapat perbedaan yang signifikan skor kualitas tidur antara kelompok kontrol dan kelompok intervensi dengan nilai $p$ value 0,001 . Hal ini menunjukkan bahwa pemeberian posisi lateral kanan efektif untuk meningkatkan kualitas tidur pasien gagal jantung.

Penelitian tentang pengaruh posisi tidur lateral kanan juga dilakukan oleh Pujiati et al (2019) dengan menggunakan desain penelitian quasi eksperimental pre and posttest. Responden dalam penelitian ini sebanyak 32 responden dengan pengumpulan data meliputi tekanan darah, respirasi, saturasi oksigen dan HR. Hasil penelitian menunjukkan pemberian intervensi posisi lateral kanan berpengaruh terhadap hemodinamik pasien CHF 30 menit setelah pemberian intervensi.

Penelitian lain juga dilakukan oleh Khasanah \& Pambudi (2015) dengan desain penelitian deskriptif komparatif. Populasi pada penelitian ini adalah seluruh pasien CHF yang dirawat di RSUD Prof. DR. Margono Soekarjo Purwokerto. Besar sampel pada penelitian ini adalah 16 responden, dengan teknik sampling menggunakan consecutive sampling. Variabel yang diteliti adalah posisi tidur dan kualitas tidur pasien CHF. Hasil penelitian menunjukkan skor rata-rata kualitas tidur kelompok perlakuan lebih kecil dari kelompok control dengan nilai $p$ value 0,005 . Hal ini menunjukkan bahwa posisi miring kanan efektif untuk meningkatkan kualitas tidur pasien CHF.

Sedangkan penelitian yang dilakukan oleh Puspita (2019) dengan desain penelitian quasy eksperiment pre and posttest without control, dengan menggunakan dua kelompok intervensi. Intervensi diberikan pada masing-masing kelompok kemudian dibandingkan. Populasi dalam penelitian ini yaitu semua pasien gagal jantung yang dirawat inap di RSUD Dr. Soedarso. Sampel yang digunakan dalam penelitian ini adalah 3636 responden dalam 2 kelompok. Teknik pengambilan sampel dalam penelitian ini adalah nonprobability sampling. Adapun hasil penelitian didapatkan bahwa terdapat perbedaan skor kualitas tidur responden sebelum dan sesudah diberikan posisi miring kanan dengan nilai $p=0,000$. Hal ini menunjukkan adanya penurunan skor kualitas tidur dari sebelum dan sesudah pemberian posisi. Hal ini juga bermakna bahwa posisi tidur miring kanan efektif meningkatkan kualitas tidur pasien gagal jantung kongestif.

Adapun penatalaksanaan lainnya yang dapat dilakukan untuk meningkatkan kualitas tidur pasien CHF yaitu dengan pemberian posisi tidur semifowler. Pada penelitian Merdekawati et al (2019) dengan desain penelitian quasy eksperimen one group pre and posttest. Populasi dalam penelitian ini adalah klien $\mathrm{CHF}$, infark miokard akut, hipertensi dan penyakit jantung koroner. Besaran sampel berjumlah 33 responden. Teknik pengambilan sampel dilakukan dengan cara accidental sampling. Hasil penelitian menunjukkan bahwa rata-rata kualitas tidur responden sebelum diberikan pengaturan posisi tidur adalah 12,27 (kualitas tidur buruk) dan setelah diberikan pengaturan posisi tidur adalah 3,36 (kualitas tidur baik) dengan nilai $p$ value $=0,000$. Artinya terdapat perbedaan signifikan nilai kualitas tidur dengan pemberian posisi tidur.

Penelitian yang dilakukan oleh Indrawati \& Nuryanti (2018) dengan desain penelitian deskriptif analitik. Sampel dipilih dengan teknik non random sampling yaitu total sampling. Jumlah sampel dalam penelitian ini adalah 40 responden yang memenuhi kriteria inklusi. Hasil penelitian menunjukkan bahwa dari 23 responden dengan posisi semifowler, 19 responden memiliki kualitas tidur dengan kategori baik. Sedangkan dari 17 responden dengan posisi tidak semifowler, sebanyak 11 responden memiliki kualitas tidur dengan kategori buruk. Hal ini bermakna bahwa ada hubungan posisi tidur dengan kualitas tidur pasien CHF.

\section{PEMBAHASAN}

Congestive Heart Failure adalah suatu kondisi dimana jantung mengalami kegagalan dalam memompa darah guna mencukupi kebutuhan sel - sel tubuh akan nutrien dan oksigen secara adekuat. ${ }^{9}$ Salah satu dampak dari kegagalan jantung dalam memompakan darah yaitu pasien merasakan gejala sesak nafas. Sesak nafas pada pasien CHF diakibatkan oleh gangguan kemampuan kontraktilitas jantung, yang menyebabkan curah jantung menjadi lebih 
rendah dari curah jantung normal sehingga darah yang dipompa pada setiap kontriksi menurun dan menyebabkan penurunan darah ke seluruh tubuh. Apabila suplai darah di paru - paru tidak lancar (darah tidak masuk ke jantung), menyebabkan penimbunan cairan di paru - paru yang dapat mengganggu proses difusi di paru - paru. ${ }^{10}$ Hal ini dapat menimbulkan gangguan tidur pada penderita gagal jantung kongestif yang berkaitan dengan berkurangnya kualitas tidur. ${ }^{11}$

Pasien CHF mengalami gangguan tidur antara lain terbangun pada malam hari atau dini hari, kesulitan bernafas atau sesak nafas pada malam hari. ${ }^{8}$ Hal ini sejalan dengan literatur Udjianti yang menyatakan CHF menimbulkan berbagai gejala klinis diantaranya dyspnea, ortopnea, pernapasan cheyne stokes, paroxymal noctural dyspnea, asites, pitting edema, berat badan meningkat, dan gejala yang paling sering dijumpai adalah sesak nafas pada malam hari, yang mungkin muncul tiba-tiba dan menyebabkan terbangun. ${ }^{9}$ Gangguan bernafas saat tidur merupakan symptom yang paling sering dilaporkan pada pasien CHF terjadi $50-75 \%$ kasus. ${ }^{12}$ Menurut Khasanah \& Pambudi, penyebab pasien gagal jantung mengalami kualitas tidur buruk dikarenakan pasien mengalami PND atau sesak nafas yang terjadi saat malam hari ketika pasien tidur selama beberapa jam. ${ }^{13}$ Sedangkan menurut Indrawati \& Nuryanti, penyebab gangguan tidur pada pasien CHF yaitu sesak nafas dan nyeri dada. ${ }^{14}$

Tindakan keperawatan yang dapat dilakukan untuk mengatasi masalah tidur pasien CHF yaitu dengan pemberian posisi lateral kanan dan semifowler. Posisi lateral kanan merupakan posisi miring dimana pasien bersandar ke samping dengan sebagian besar berat tubuh berada pada pinggul dan bahu. ${ }^{8}$ Pemberian posisi lateral kanan dapat membantu mengatasi gangguan tidur pasien CHF. Hal ini dikarenakan pada saat tidur dengan posisi lateral kanan maka aktivitas saraf simpatis menjadi menurun sedangkan aktivitas parasimpatis meningkat, aliran balik vena dan preload ke ventrikel kiri meningkat, sehingga menghasilkan peningkatan curah jantung dan tekanan aorta. Sedangkan posisi semifowler adalah posisi setengah duduk dimana bagian kepala tempat tidur lebih tinggi atau dinaikan. Posisi ini diberikan untuk mempertahankan kenyamanan dan memfasilitasi fungsi pernafasan pasien. ${ }^{15}$
Menurut hasil penelitian Puspita posisi semifowler efektif meningkatkan kualitas tidur pasien gagal jantung karena posisi tersebut meningkatkan ekspansi paru sehingga tidak tertekan oleh diafragma, sehingga pasien dapat bernafas dengan lebih lega, dan pasien dapat mengurangi gangguan tidur yang muncul akibat sesak yang muncul pada malam hari atau sering disebut paroximal nocturnal dyspnea sebagai manifestasi gagal jantung. ${ }^{8}$ Selain itu dengan posisi semifowler, akumulasi cairan di rongga torak dapat berkurang sehingga mengurangi beban jantung. Dengan demikian kejadian PND dan dyspnea dapat berkurang sehingga kualitas tidur meningkat. Mengatur pasien dalam posisi tidur semifowler akan membantu menurunkan konsumsi oksigen dan meningkatkan ekspansi paru serta mengatasi kerusakan pertukaran gas yang berhubungan dengan membran alveolus. Dengan posisi semifowler, sesak nafas berkurang dan sekaligus akan meningkatkan durasi tdur klien. ${ }^{16}$

\section{SIMPULAN DAN SARAN}

Berdasarkan 7 jurnal yang telah direview penulis, maka dapat disimpulkan bahwa pengaturan posisi tidur lateral kanan dan semifowler efektif untuk meningkatkan kualitas tidur pasien Congestive Heart Failure. Selain itu, pengaturan posisi tidur harus diberikan berdasarkan grade gagal jantung pasien CHF. Dari hasil studi literatur peneliti mengharapkan peran perawat dan peneliti selanjutnya agar dapat menerapkan intervensi pemberian posisi tidur lateral kanan dan semifowler untuk meningkatkan kualitas tidur pasien CHF yang sudah terbukti efektif berdasarkan evidence based. Posisi tidur lateral kanan sebaiknya diberikan pada pasien CHF dengan NYHA I \& II, sedangkan posisi tidur semifowler diberikan pada pasien dengan NYHA III \& IV.

\section{DAFTAR PUSTAKA}

1. Irnizarifka. Buku Saku Jantung Dasar. Jurnal Kesehatan Budi Luhur. Bogor: Ghaila Indonesia; 2011.

2. World Health Organization. Prevention of Casdiovascular Disiase. Switzerland: World Health Organization; 2016.

3. Kementerian Kesehatan R.I. Laporan Hasil Riset Kesehatan Dasar 2018. Jakarta: Kementerian Kesehatan R.I.; 2018.

4. Davey P. At A Gilance Medicine. Jakarta: EGC; 2005. 
5. Guyton, A. C, Hall JE. Buku Ajar Fisiologi Kedokteran. 12 ed. Jakarta: EGC; 2014.

6. Potter, Perry. Buku Ajar Fundamental Keperawatan. 4 ed. Jakarta: EGC; 2010.

7. Yesni M. Pengaruh Terapi Posisi Lateral Kanan Terhadap Kualitas Tidur Pasien Gagal Jantung Di Rsup M Djamil Padang. J Akad Baiturrahim Jambi [Internet]. 2019;8(1):117. Tersedia pada: http://jab.stikba.ac.id/index.php/jab/article/view $/ 109 / 81$

8. Puspita D. Efektifitas Posisi Tidur Miring Kanan dan Semifowler Terhadap Kualitas Tidur Pada Pasien Gagal Jantung Kongestif Di RSUD Dr. Soedarso Pontianak. J Keperawatan dan Kesehat [Internet]. 2019;10(1):35-47. Tersedia pada: http://jurnal-stikmuhptk.id/index.php/JK2/article/view/105

9. Udjianti W. Keperawatan Kardiovaskuler. Jakarta: Salemba Medika; 2010.

10. Smletzer, Bare. Keperawatan Medikal Bedah, brunner \& suddarth. 8 ed. Jakarta: EGC; 2013.

11. Khayat R, Jarjoura D, Porter $\mathrm{K}$, Sow A, Wannemacher J, Dohar R, et al. Sleep
Disordered Breathing and Post Discharge Mortality in Patients with Acute Heart Failure. Eur Heart J. 2015;36(23):1463-9.

12. Mehra R, Gotlieb D. A Paradigm Shift in the Treatment of Central Sleep Apnea in Heart Failure. Chest. 2018;148(4):848-51.

13. Khasanah S, Pambudi HS. Kualitas Tidur Pasien Congestive Heart Failure (CHF) Pada Posisi Miring Ke Kanan. Viva Med. 2015;7(12):86-95.

14. Indrawati L, Nuryanti L. Hubungan Posisi Tidur Dengan Kualitas Tidur Pasien Congestive Heart Failure. J Kesehat Budi Luhur [Internet]. 2018;11(2):401-10. Tersedia pada: http://jurnal.stikesbudiluhurcimahi.ac.id/index.p $\mathrm{hp} / \mathrm{jkbl} / \mathrm{article} / \mathrm{view} / \mathrm{jkb} 111217$

15. Alimul A. Kebutuhan Dasar Manusia Aplikasi Konsep dan Proses Perawatan. Jakarta: Salemba Medika; 2009.

16. Doengoes. Rencana asuhan keperawatan: pedoman untuk perencanaan dan pendokumentasian perawatan pasien. Jakarta: EGC; 2011. 